\title{
Impact of Corporate Taxation On Dividend Policy of Quoted Firms in Nigeria
}

\author{
Oloyede, John Adebayo \\ Department of Banking and Finance, Ekiti State University, \\ Ado- Ekiti, Ekiti state Nigeria. \\ Olaoye, Clement Olatunji \\ Department of Banking and Finance, Ekiti State University, \\ Ado- Ekiti, Ekiti state Nigeria. \\ Oluwaleye, Taiwo Olarinre \\ Department of Accounting, Ekiti State University, \\ Ado- Ekiti, Ekiti State, Nigeria.
}

\begin{abstract}
This study examined the impact of corporate taxation on dividend policy of selected quoted firms in Nigeria. Specifically, it analyzed the impact of company income tax and educational tax on dividend per share of 10 randomly sampled consumer goods firms. Data used were collected from the published annual reports of the selected firms over a period of 5 years spanning from 2011 to 2015. Panel data estimation techniques employed in the study are pooled OLS estimation, fixed effect estimation and random effect estimation. The most consistent and efficient estimation result showed that company income tax has insignificant positive impact on dividend per share $\beta=.0000659$ ( $p=0.705>0.05$ ), education tax exert insignificant positive impact on dividend per share $\beta=0.0142983(p=0.088>0.05)$. It was concluded in the study that corporate taxation has no clear cut influence on dividend distribution policy of quoted consumer goods firms in Nigeria. Thus, firms are advised to devise investment and financing framework that will give room for adequate and consistent dividend distribution, and strive toward capacity expansion and operational efficiency to foster increased profitability, which is a sine-qua-non for higher dividend distribution.
\end{abstract}

Keywords: Corporate taxation, Dividend Policy, Education Tax, Company Tax, Quoted Firms.

\section{INTRODUCTION}

Dividend policy is a sensitive subject of discourse in corporate financial management, as it relates to decisions regarding how the present and future finance of an organization is catered for without sending negative signals to shareholders (Okafor and Mgbame, 2011). Dividend policy revolves around making decision between distribution of present return and reinvestment of the same for future return (Pandey \& Ashvini, 2016; Kouser, Luqman, Yaseen, and Azeem, 2015). The framework of dividend policy of any organization reflects on the availability of investment opportunities and how these opportunities are being embraced for future expansion and growth (Afza \& Mirza, 2011). Dividend policy is a corporate finance decision on transfer of value in form of share dividend from an organization to its shareholders, out of the profit made from the business operation for a specified period of time usually a year (Okafor and Mgbame, 2011). Expanding on the importance of dividend policy as management strategy for sustaining improved corporate performance. Ajanthan (2013) established that effective management of an organization as perceived by shareholders connect to how earnings is distributed in form of dividend over time. Structure of dividend policy is a framework that outlines the fraction of a company's earnings that is declared as 
return on shareholder's investment for a specific period of time, either in form of cash dividend or stock dividend (Abdul and Muhibudeen, 2015). Relating dividend policy to corporate performance had been given keen attention by scholars around the world such as Pandey and Ashvini, (2016); Kouser, Luqman, Yaseen, and Azeem, (2015); Zameer, Rasool, Igbal and Arshad, (2013); Amidu, (2007); Marfo-Yiadom, and Agyei, (2011); Murekefu, and Ouma, (2013); Priya, and Nimalathasan, (2013). Observably, such investigation had also found its path among scholars in Nigeria such as Abdul and Muhibudeen, 2015; Akani, and Sweneme, 2016; Adesola, and Okwong, 2009; Ajanthan, 2013; Okafor and Mgbame, 2011; Abiola, 2014; Akani, and Sweneme, 2016; Jacob and Akinselure, 2016; Yusuf 2015 to mention but few.

Overview of the relevance of dividend policy in the discourse of corporate performance on empirical ground reflects divergence yet to be resolved (Abdul and Muhibudeen, 2015). Over the years, Nigerian tax system has been geared towards raising funds to meet government expenditure at all levels (federal, state, and local), neglecting the need to sustain a system potent enough to foster rapid industrial expansion and growth (Ezugwu and Akubo 2014). This is evident by the poor level of infrastructural facilities in the country, resulting from poor allocation of revenue generated by the government for development project, not to mention the undue and unchecked perennial problem of public fund misappropriation in the country. This malaise had hither-to dampen the prospect of companies for growth and expansion in the country. In clear terms, firms now pay taxes without any identifiable benefit accrued to them or the environment of operation. In Nigeria today companies could not but device means to evade, avoid and/or objectively transfer tax burden to the society. They either increase prices of goods and services and/or deny shareholders return on their investment in the name of retaining earnings for reinvestment. Expanding on the issue of dividend payment, it can be observed that most of firms quoted on the Nigeria stock exchange fill relax even when they don't declare any dividend at the end of the financial calendar. For instance in 2016 only 82 companies declared dividend out of all firms quoted on the Nigeria stock exchange, with financial service sector, consumer goods sector and industrial goods sector dominating the list (Proshare, 2017).

Without mincing words, there is dearth of empirical investigation on the nexus between corporate taxation and dividend policy in Nigeria, majority of studies on dividend policy had focused on either the determinants of dividend policy (Mukhtar 2015; Odeleye, 2015; Odesa, and Ekezie, 2015; Kurawa, and Ishaku, 2014; Ajide, and Aderemi, 2014; Olowe and Soyoye 2014) or impact of dividend policy on the performance and/or stock value of firms in the country (Abdul and Muhibudeen, 2015; Akani, and Sweneme, 2016; Adesola, and Okwong, 2009; Ajanthan, 2013; Okafor and Mgbame, 2011; Abiola, 2014; Akani, and Sweneme, 2016; Jacob and Akinselure, 2016; Yusuf 2015). Observably, the few studies (Uwuigbe and Olowe, 2013; Odia, and Ogiedu, 2013; Nnadi, and Akpomi, 2008; Samuel, and Inyada, 2010) that focused on the impact of corporate taxation on dividend policy in Nigeria, did not take into consideration the uniqueness of sampled firms. Hence, this study analyzed the connection between corporate taxation and dividend policy of incorporating the heterogeneity effect into the analysis. Specifically, this study analyzed the impact of company income tax on dividend per share of quoted consumer goods firms as well as impact of education tax on dividend per share of quoted consumer goods firms.

\section{Conceptual Issues}

\section{LITERATURE REVIEW}

There are a number of conceptual issues that need clarification before going into the study. These issues include corporate taxation, dividend policy and determinants of dividend policy, among others. Corporate taxation stems from the fact that businesses are regarded as separate 
entity from their owner, thus making imposition of a compulsory levy called corporate tax inevitable for governments around the world (Uwuigbe \& Olowe, 2013). Corporate tax is a tax imposed on the net profit (earnings) of a company after all deductions (expenses/expenditures) has been accounted for. Corporate tax is a form of compulsory levy placed by the government on profits accruing in, received from, brought into or received in Nigeria from, any trade or business, rent or any premium arising from a right granted to any other person for the use or occupation of any property, dividends interest, discounts, charges or annuities, any other amount not falling within the above categories but qualifying as annual profits or gains or any amount deemed to be income or profits of a business entity (Nnadi and Akpomi, 2008). Taxes (corporate or otherwise) are compulsory contribution imposed by the government. Though tax payers may receive nothing identifiable in return for their contribution, they nevertheless have the benefit of living in a relatively educated, health and safe society. Taxation is not only a means for government to acquire resources. It has an important role in achieving equality and distributive social and economic needs (Samuel and Inyada, 2010).

Conceptualizing dividend policy starts with establishing in clear term the meaning of dividend. According to Davies \& Pain (2002) dividend is the amount payable to shareholders from profit or distributable reserves. This is an obligation that must be fulfilled by quoted companies annually, bi-annually, quarterly on interim or final basis (Samuel \& Inyada, 2010). In the words of Droughty (2000) dividend is the payment made by firms to stakeholders as their fraction of total earnings for period of time. According to Samuel \& Inyada (2010) dividend policy is the framework of decision regarding the amount of profit that will be distributed to the shareholders as return on investment, and the fraction that will be retained by the company for investment purpose. Oloyede and Ajayi (2005) explained that, the objective of a dividend policy should be to maximize the shareholders' return so that value of his investment is maximized. Dividend policy revolves around making decision between distribution of present return and reinvestment of the same for future return (Pandey \& Ashvini, 2016; Kouser, Luqman, Yaseen, and Azeem, 2015).

As relayed in Abiola (2014) there is empirical evidence that dividend policy of a firm is determined by both current and past year's profit among other things. Meaning the position of performance of a firm in terms of profitability is vital in the design of dividend policy of a firm. Ranti (2013) submitted from his survey that determinants of dividend policy are industry specific, and connect without mincing words to the anticipated level of future earnings. The corollary of this position is that what determines the dividend framework of a company in a particular industry, might not be sufficient enough to explain the dividend policy design of a firm in another industry. According to Pandey \& Ashvini (2016) dividend policy of firms is determined by factors including debt-equity ratio, earnings, corporate tax, earnings per share, and firms' size. As relay by Zameer, Rasool, Ighal and Arshad (2013) factors influencing the dividend policy of a firm include liquidity, earnings, Kurawa \& Ishaku (2014) identified corporate governance as a determinant of dividend policy while Sakinc \& Gungor (2015) identified ownership structure as a determinant of dividend policy of a firms.

\section{Theoretical Issues}

Theoretical issues that need review as framework of analysis in this study include Dividend Irrelevance Theory and Bird-in-the hand Dividend Theory, among others.

Dividend irrelevant theory was developed by Miller and Modigliani in the early1960's. The basic proposition of this theory is that under the assumption of perfect capital market, dividend policy adopted by a firm is irrelevant (Miller \& Modigliani, 1961). Their argument 
was that given a perfect market dividend policy has no effect on either the price of a firm's stock or its cost of capital, shareholders wealth is not affected by the dividend decision and therefore they would be indifferent between dividends and capital gains. The reason for their indifference is that shareholder wealth is affected by the income generated by the investment decisions a firm makes, not by how it distributes that income. Therefore, in M\&M's world, dividends are irrelevant. The position of dividend irrelevance theory is that regardless of how the firm distributes its income, its value is determined by its basic earning power and its investment decisions (Al-Malkawi Rafferty \& Pillai, 2010).

They stated that “...given a firm's investment policy, the dividend payout policy it chooses to follow will affect neither the current price of its shares nor the total returns to shareholders".

In other words, investors calculate the value of companies based on the capitalised value of their future earnings, and this is not affected by whether firms pay dividends or not and how firms set their dividend policies. M\&M go further and suggest that, to an investor, all dividend policies are effectively the same since investors can create "homemade" dividends by adjusting their portfolios in a way that matches their preferences. M\&M based their argument upon idealistic assumptions of a perfect capital market and rational investors (Al-Malkawi Rafferty \& Pillai, 2010).

The assumptions of a perfect capital market necessary for the dividend irrelevant hypothesis can be summarized as follows:

(i) no differences between taxes on dividends and capital gains;

(ii) no transaction and flotation costs incurred when securities are traded;

(iii) all market participants have free and equal access to the same information (symmetrical and costless information);

(iv) no conflicts of interests between managers and security holders (i.e. no agency problem); and

(v) all participants in the market are price takers. Given the importance of M\&M's argument in the dividend policy debate, the following section provides their proof of irrelevancy.

\section{Bird-in-the-hand Dividend Theory:}

Bird-in-the-hand theory is one of the leading theories of dividend policy in the 1960's; advocates of this theory include Gordon (1963), Lintner (1962). The basis for this theory is that in a world of uncertainty and imperfect information, dividends are valued differently to retained earnings (or capital gains). Investors prefer the "bird in the hand" of cash dividends rather than the "two in the bush" of future capital gains. Increasing dividend payments, ceteris paribus, may then be associated with increases in firm value. As a higher current dividend reduces uncertainty about future cash flows, a high payout ratio will reduce the cost of capital, and hence increase share value. That is, according to the so-called "bird-in-the hand" hypothesis (henceforth BIHH) high dividend payout ratios maximize a firm's value (Al-Malkawi Rafferty \& Pillai, 2010)

Gordon and Lintner claimed that Modigliani and Miller made a mistake assuming lack of impact of dividend policy on firm's cost of capital. They argued that lower payouts result in higher costs of capital. They suggested that investors prefer dividend as it is more certain than capital gains that might or might not appear if they let the firm retain its earnings. The authors indicated that the higher capital gains/dividend ratio is the larger total return is required by investors due to increased risk. In other words, Gordon and Lintner claimed that one percent drop in dividend payout has to be offset by more than one percent of additional growth (Gordon, 1960; Lintner, 1962) 
Investors are risk averse and believe that incomes from dividends are certain rather than incomes from future capital gains; therefore they predict future capital gains to be risky propositions. They discount the future capital gains at a higher rate than the firm's earnings, thereby evaluating a higher value of the share. Notably, bird in the hand theory is based on the following assumptions:

1. corporation can only finance itself through equity i.e. capital structure with no debt

2. there is unavailability of external financing, therefore, corporation can only finance expansion through retaining of its earnings

3. returns are constant and diminishing marginal efficiency of investment is not considered

4. there is constant cost of capital

However, this study will be hinged on the framework of relevant dividend theory advocated by Gordon (1963), and Lintner (1962).

\section{EMPIRICAL REVIEW}

A number of empirical studies such as Pandey and Ashvini (2016), Sajid, Bilal, Shafiq and Mehran (2012), Uwuigbe and Olowe (2013) Samuel and Inyada (2010) had investigated the impact of corporate taxation on dividend policy of quoted firms in the financial and accounting literature.

Pandey and Ashvini (2016) analysed the determinants of dividend policy of FMCG sector in India, the study employed various factors affecting dividend policy such as dividend payout ratio (DPR), debt equity ratio (DER), earnings (ERN), earning per share (EPS), corporate tax (CT) and firm size (FS) taken only 12 companies out of 15 sectoral index for NSE. It used ordinary least square for data from 2003-2012. The result revealed that DPR, DER, ERN and CT have significant impact on EPS and also good predictors of dividend payout in FMCG sector.

In the work of Sajid, Muhammed, Bilal, Shafiq and Mehran (2012), titled taxes and dividend policy. The study investigated the association between dividends, profit and taxes of 120 companies listed in Karachi Stock Exchange from 2000-2011. Data were sourced from Karachi Stock Exchange, Securities and Exchange Commission of Pakistan, State Bank of Pakistan and the Audited Annual Reports, Panel data technique and standard multiple regression were used to analysed the data. It was found that there is statistically insignificant but positive link between profit and taxes while dividend has direct positive correlation with profit.

Uwuigbe and Olowe (2013) examined the effects of company income tax on dividend policy of firms in Nigeria using judgmental sampling techniques and regression analysis method. Data were gathered for 40 listed firms in the Nigerian stock exchange market from Central Bank of Nigeria Statistical Bulletin and corporate annual reports for the period of 2006-2010. The study revealed in its findings that there is a significant positive relationship between the company income tax and the dividend payout of the sampled firms in Nigeria. Hence, it was concluded in the study that a change in corporate income tax rate will significantly affect the dividend policies of the sampled firms in Nigeria.

Samuel and Iyanda (2010) analyzed the effect of company income tax on dividend policy of financial institutions in Nigeria using a survey research method and regression technique of correlation analysis and data were gathered for 15 financial institutions. The study revealed correlation coefficient of 0.552 which means that company income tax has perfect positive correlation with the dividend policy, coefficient of determination of 0.305 which shows that 
$31 \%$ of variation in dividend is explained by company tax and $96.7 \%$ confidence level indicating that the impact is significant. Thus, concluded that a change in company tax will affect the dividend payment. Therefore, based on the empirical literature, there is no consensus that a change in company income tax rate will affect the dividend policy. Some findings in empirical literature revealed that a change in company income tax rate will have a positive impact on dividend policy, some resulted that, a change in company income tax rate will have a negative effect on dividend policy, others emphasized that dividend policy has a direct positive correlation with firms profitability.

\section{Model Specification}

\section{METHODOLOGY}

Model to be tested in this study specified a single equation model to capture the causal-effect relationship between corporate taxation and dividend policy using disaggregated corporate tax variable include Company Income Tax (CIT) and Education Tax (EDT), and Dividend per Share (DPS) as proxy for dividend policy, with Firm Size (FZ) as control variable. The model is specified in functional and linear forms below:

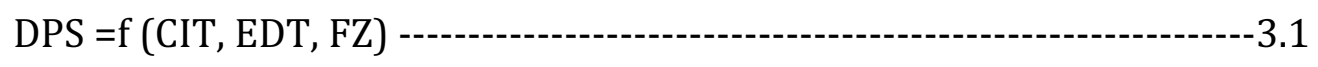

In equation 3.1, Dividend per share is expressed as a function of CIT, EDT and FZ while the linear form of equation 3.1 is presented in equation 3.2 below:

$$
D P S_{i t}=\alpha_{0}+\alpha_{1} C I T_{i t}+\alpha_{2} E D T_{i t}+\alpha_{3} F Z_{i t}+\mu_{i t}
$$

Where:

DPS $=$ Dividend per share

CIT = Company income tax

$\mathrm{ED}=$ Education tax

FZ = Firm size

$\alpha_{0}=$ Intercept

$\alpha_{1}, \alpha_{2}, \alpha_{3}=$ Coefficients

$\mu_{\mathrm{it}}=$ error term.

\section{Apriori Expectation}

The apriori expectation of the model is that all the independent variables are expected to have a negative relationship on the dividend per share which is the proxy for dividend policy except the firm size which is expected to be positive. That is, an increase in company income tax and education tax will result in decrease in dividend per share.

$\alpha_{1}, \alpha_{2}, \alpha_{3}<0$ connotes that an increase in the independent variables will lead to decrease in dividend per share.

\section{Estimation Technique}

This study adopted correlation and panel data methods of analysis. Techniques of panel data analysis used in the study covered pooled OLS estimation, Fixed effect estimation (cross sectional and period specific) based on the framework of Least Square Dummy Variable (LSDV) model, random effect estimation, alongside post estimation test such as restricted F-test, Hausman test, heteroscedasticity Wald test, Wooldridge autocorrelation test, Pesaran crosssectional dependence test. 


\section{Scope and Source of Data}

The study focused on the consumer goods firms quoted on the Nigerian stock exchange. Specifically, the study randomly sampled 10 firms from the total 23 quoted consumer goods firms. Sampled firms include Guinness Nigeria Plc., Honeywell Flour Mills Plc., Nascon Allied industries Plc., Nestle Nigeria Plc., Nigerian Breweries Plc., Pz Cusson Plc., Unilever Nigeria Plc., Flour Mills of Nigeria Plc., Dangote Sugar Refinery Plc., 7up bottling Company Plc. Data used in the study were collected from the published annual reports of the selected firm over the period of 5 years (2011 to 2015).

\section{DATA ANALYSIS AND FINDINGS}

This section presents results of analysis conducted in the study which include correlation analysis result, pooled OLS analysis result, fixed effect analysis result, random effect analysis result, as well as post estimation test results

The Correlation Analysis result is presented in Table 4.1

Table 4.1: Correlation Matrix

\begin{tabular}{|c|l|l|l|l|}
\hline & DPS & CIT & EDT & FZ \\
\hline DPS & 1.0000 & & & \\
\hline CIT & 0.0686 & 1.0000 & & \\
\hline EDT & 0.1603 & 0.8174 & 1.0000 & \\
\hline SSFZ & 0.1617 & 0.5981 & 0.8300 & 1.0000 \\
\hline
\end{tabular}

Sources: Authors' Computation, (2017)

The table revealed that there is positive correlation between dividend per share and other variables in the model including company income tax, education tax and firm size. Notably, correlation coefficient reported in table 4.1 is weak for dividend per share and other variables, thus reflecting weak interrelationship between dividend per share and corporate tax variables including company income tax, education tax, as well as firm's size. Correlation between pair of explanatory variables as reported in table 4.1 is positive, for pair of company income tax, education and Firms' size with considerably strong magnitude. As reported in table 4.1 the correlation coefficient stood at $0.0686,0.1603,0.1617,0.8174,0.5981,0.8300$ for DPS and CIT, DPS and EDT, DPS and FZ, CIT and EDT, CIT and FZ, EDT and FZ respectively.

The result of Pooled OLS Estimation are provided in table 4.2

Table 4.2: Pooled OLS Parameter Estimates

\begin{tabular}{|c|c|c|c|c|}
\hline Variable & Coefficient & $\begin{array}{l}\text { Standard } \\
\text { Error }\end{array}$ & T-Test Values & Probability \\
\hline C & 2.669105 & 1.574658 & 1.70 & 0.097 \\
\hline CIT & -.0002271 & .0003328 & -0.68 & 0.498 \\
\hline EDT & .0047732 & .0066756 & 0.72 & 0.478 \\
\hline FZ & .0048966 & .0022565 & 2.17 & 0.003 \\
\hline
\end{tabular}

R-square $=0.6381$

Adjusted R-square $=0.6247$

F-statistics $=30.61$

Prob(F-stat) $=0.0040$

\section{Sources: Authors' computation, (2017)}

The table revealed specific coefficient estimates of $-0.0002271,0.0047732$ and 0.0048966 for company income tax, education tax and firm size respectively, with probability values of 0.498 , 
0.478, and 0.003. Result showed that company income tax has insignificant negative impact on dividend per share, while education tax has positive insignificant impact on dividend per share. In specific term the result revealed that dividend per share will decline insignificantly by 0.0002271 naira for every one million increase in company income tax paid on the average by any of the sampled firm, while for every one million naira increase in the education tax paid, dividend per share will increase by 0.0047732 naira. R-square statistics reported in table 4.2 revealed that about $64 \%$ of the systematic variation in dividend per share can be explained by company income tax, education tax and firms size. F-statistics of 30.61 and probability value of 0.0040 reported in table 4.2 revealed that the explanatory variables (company income tax, education tax, firm's size) can explain significant percentage of the variation in dividend per share of firm's sampled in the study.

The result of the Fixed Effect Panel Analysis is reported in Table 4.3

Table 4.3: Fixed Effects Estimates (Cross-Sectional and Period Specific)

\begin{tabular}{|c|c|c|c|c|c|}
\hline \multicolumn{3}{|c|}{ CROSS-SECTIONAL SPECIFIC EFFECT } & \multicolumn{3}{|c|}{ TIME SPECIFIC EFFECT } \\
\hline Variables & Coefficients & Prob & Variables & Coefficients & Prob \\
\hline $\mathrm{C}$ & -3.094731 & 0.498 & $\mathrm{C}$ & 2.242871 & 0.397 \\
\hline CIT & .0000659 & 0.705 & CIT & -.0002004 & 0.586 \\
\hline EDT & .0142983 & 0.088 & EDT & .0049454 & 0.491 \\
\hline $\mathrm{FZ}$ & .0039678 & 0.003 & $\mathrm{FZ}$ & .0050549 & 0.006 \\
\hline Effects & & & Effects & & \\
\hline HONEYWELL & 1.01146 & 0.798 & 2012 & -.132859 & 0.969 \\
\hline NASCON & 2.344882 & 0.577 & 2013 & .749797 & 0.829 \\
\hline NESTLE & 17.89913 & 0.000 & 2014 & 1.326196 & 0.707 \\
\hline NIG BREWERIES & -20.08957 & 0.020 & 2015 & .8042949 & 0.823 \\
\hline PZ CUSSON & 1.386694 & 0.720 & & & \\
\hline UNILEVER & .4491244 & 0.901 & & & \\
\hline $\begin{array}{l}\text { FLOUR MILLS OF } \\
\text { NIG }\end{array}$ & -2.94806 & 0.340 & & & \\
\hline DANGOTE SUGAR & -3.730937 & 0.117 & & & \\
\hline 7UP & 1.434084 & 0.665 & & & \\
\hline \multicolumn{3}{|c|}{$\begin{array}{l}\text { R-square }=0.8344 \\
\text { Adjusted R-square }=0.7807 \\
\text { F-statistics }=15.54 \\
\text { Prob(F-stat) }=0.0000\end{array}$} & \multicolumn{3}{|c|}{$\begin{array}{l}\text { R-square }=0.4437 \\
\text { Adjusted R-square }=0.4157 \\
\text { F-statistics }=20.27 \\
\text { Prob(F-stat) }=0.0007\end{array}$} \\
\hline
\end{tabular}

\section{Sources: Authors' Computation, (2017)}

The table reflects impact of company income tax, education tax, controlled by firms' size, when heterogeneity effect across firms and over time is incorporated into the models. Table 4.3 revealed that the impact of both company income tax and education tax is positive when firm's heterogeneity effect is recognized, though such impact still remained insignificant for both variables. On the other hand, the impact of company income tax on dividend per share is negative when period heterogeneity effect is incorporated into the analysis, while education tax reflect positive insignificant. Table 4.3 also reported differential intercept term of firms, from the intercept term of the reference cross sectional unit (Guinness Plc.). Specifically cross sectional deviation stood at 1.01146, 2.344882, 17.89913, -20.08957, 1.386694, .4491244, 2.94806, -3.730937, and1.434084 for Honeywell Flour Mills Plc., Nascon Allied industries Plc., Nestle Nigeria Plc., Nigerian Breweries Plc., Pz Cusson Plc., Unilever Nigeria Plc., Flour Mills of 
Nigeria Plc., Dangote Sugar Refinery Plc., Seven Up bottling Company Plc. respectively. Deviation from the intercept term of the reference period (2011) stood at -.132859, .749797, 1.326196, .8042949 for $2012,2013,2014$, and 2015 respectively. R-square values reported in table 4.3 stood at 0.8344 and 0.4437 for cross sectional specific effect and period specific effect estimations respectively. It thus implies that about $83 \%$ of the systematic variation in the dividend per share can be explained by variations in all the included explanatory variables when cross section heterogeneity effect is incorporated into the model, while about $44 \%$ of the systematic variation in the dependent variable can be explained by variation in all the explanatory variables when period effect is incorporated into the model.

The result of Random Effect Analysis is stated in Table 4.4

Table 4.4: Random Effect Estimation

\begin{tabular}{|c|c|l|l|l|}
\hline Variable & Coefficient & $\begin{array}{l}\text { Standard } \\
\text { Error }\end{array}$ & Z-Test Values & Probability \\
\hline C & .6146008 & 3.104934 & 0.20 & 0.843 \\
\hline CIT & .0000436 & .0001719 & 0.25 & 0.800 \\
\hline EDT & .005784 & .0058268 & 0.99 & 0.321 \\
\hline FZ & .0046665 & .0017676 & 2.64 & 0.002 \\
\hline
\end{tabular}

R-square $=0.4262$

Wald chi2 (5) $=12.83$

Prob $>$ chi $2=0.0085$

Sources: Authors' computation, (2017)

The result revealed that when the heterogeneity effects are subsumed into the random term of the model, the impact of both company income tax and education tax is positive and insignificant. In specific terms the reported coefficient estimates in table 4.4 stood at $0.0000436,0.005784$, and 0.0046665 for company income tax, education tax, and firm's size, alongside probability values of $0.800,0.321$, and 0.002 respectively. R-square statistics reported in table 4.4 stood at 0.4262 which connotes that about $43 \%$ of the systematic variation in dividend per share can be explained by company income tax, education tax and firm's size.

\section{Post Estimation Test}

The result of the Post Estimation Test is presented in Table 4.5

Table 4.5: Restricted F-Test of Heterogeneity (Cross- Sectional and Time Specific)

\begin{tabular}{|l|l|l|}
\hline & F-statistics & Probability \\
\hline Cross sectional & 19.77 & 0.0000 \\
\hline Time specific & 0.06 & 0.9927 \\
\hline
\end{tabular}

Sources: Authors' Computation, (2017)

The table reveals result of the heterogeneity test conducted with respects to both crosssectional and period specific effect. Reported in table 4.5 are f-statistics values of 19.77 and 0.06 with probability values of 0.0000 , and 0.9927 for cross sectional and period specific effect respectively. Result showed that there is enough evidence to reject the null hypothesis that all differential intercept corresponding to the cross sectional specific units are equal to zero, but otherwise for the period specific intercepts. Therefore it can be concluded that there is only cross sectional heterogeneity/uniqueness effect among the selected firms. Thus pooled OLS estimator restriction is not valid as cross-sectional heterogeneity effect is too significant to be ignored. 


\section{Hausman Test}

The result of Hausman Test is provided in table 4.6

Table 4.6: Hausman Test

\begin{tabular}{|l|l|l|}
\hline Null hypothesis & Chi-square stat & Probability \\
\hline $\begin{array}{l}\text { Difference in coefficient not } \\
\text { systematic }\end{array}$ & 52.88 & 0.0041 \\
\hline
\end{tabular}

Sources: Authors' Computation, (2017)

The table reveals a chi-square value of 52.88 alongside a probability value of 0.0041 . The result shows that there is enough evidence to reject the null hypothesis that differences in coefficients of fixed effect estimation and random effect estimation is not significant. Thus making fixed effect cross sectional specific estimation presented in table 4.3 most consistence and efficient estimate for investigating the impact of corporate taxation on dividend policy of quoted firms sampled in the study.

The result of other post estimation tests are presented in Table 4.7

Table 4.7. Other Post Estimation Test result

\begin{tabular}{|c|c|c|}
\hline \multicolumn{3}{|c|}{ Wald test } \\
\hline Null hypothesis & Statistics & Probability \\
\hline Panel homoscedasticity & 40.3029 & 0.5821 \\
\hline \multicolumn{3}{|c|}{ Pesaran test } \\
\hline Null hypothesis & Statistics & Probability \\
\hline $\begin{array}{c}\text { No cross sectional } \\
\text { dependence }\end{array}$ & 1.043 & 0.2968 \\
\hline \multicolumn{2}{|c|}{ Wooldridge test } \\
\hline Null hypothesis & Statistics & Probability \\
\hline $\begin{array}{l}\text { No AR(1) panel } \\
\text { autocorrelation }\end{array}$ & 60.3718 & 0.0963 \\
\hline
\end{tabular}

Sources: Authors' Computation, (2017)

The table reported results of post estimation tests conducted to confirm if the specified model is in tune with basic assumptions underlining the panel estimation conducted in the study. The result showed that there is no evidence to reject the null hypothesis of panel homoscedasticity, null hypothesis of no cross sectional dependence and null hypothesis of no AR (1) panel autocorrelation. Hence it can be established that result of post estimation test reported in table 4.7 validate assumptions of equal variance of residual terms, cross sectional independence and absence of serial autocorrelation, which reflect that the model is fit for inferential analysis of the observed impact of company income tax and education tax on dividend per share.

Following evaluation of estimators employed in this study, it was established that the most consistent and efficient estimation presented in table 4.3 for cross sectional specific effect were company income tax, and education tax which have positive insignificant impact on dividend per share. The finding revealed that corporate taxation disaggregated into company income tax and education tax has no significant impact on dividend policy measured in terms of dividend per share. By implication the revealed positive impact connotes that increase in company income tax and education tax herald increase in the dividend per share distributed to shareholders in the same year. Though, the observed positive influence of company income tax and education tax is not statistically significant, however increasing corporate taxation either 
in form of company income tax or education tax is suggestive of higher dividend per share policy option by quoted firms. This could be traced to the fact that corporate tax paid in form of company income tax, and education tax are fixed fraction of the profit before tax of any company (except in situation of tax concession), as such the higher such a fraction, the higher the expected dividend per share because it's a reflection that the company is more profitable in that period.

Therefore, the finding of this study is consistent with the result of Sajid, Muhammad, Bilal and et al (2012) and proof otherwise to the apriori expectation of this study although, the dividend policy proxy is positive as expected.

\section{SUMMARY AND CONCLUSION}

This study showed that corporate taxation has no clear cut influence on the dividend distribution policy of quoted firms, especially firms in the consumer goods industry. Disaggregated corporate tax variables including company income tax and education tax has insignificant impact on dividend per share paid by firms. The direction of causal-effect relationship between corporate taxation variables and dividend policy proxy is positive, which is suggestive of the fact that increased corporate taxation culminate into higher dividend policy, holding other things constant, thus reflecting that in the same period, higher corporate taxation herald higher dividend policy. Result of the study gave evidence that corporate taxation is not a determinant factor of dividend policy of firms operating in an economy like Nigeria with fixed corporate tax rate. Hence quoted firms are advised to work out investment and financing framework that will give room for adequate and consistent dividend distribution, and also strive towards expanding their capacity and operational efficiency so as to spur profitability, which is a sine-qua-non for higher dividend distribution.

\section{References}

Abdul, A., \& Muhibudeen, L. (2015). Relationship between Dividend Payout and Firms' Performance: Evaluation of Dividend Policy of Oando Plc. International Journal of Contemporary Applied Sciences, 2(6), 56-71

Abiola, J.O (2014). Measuring and Analyzing the Effects of Dividend Policy in Banking Profits and Growth. Journal of Policy and Development Studies, 9(1), 167-178

Adesola, W. A. \& Okwong, A. E. (2009). An Empirical Study of Dividend Policy of Quoted Companies in Nigeria. Global Journal of Social Sciences, 8(1), $85-101$.

Afza, T., \& Mirza, H. H. (2011). Do mature companies pay more dividends? Evidence from Pakistani stock market. Mediterranean Journal of Social Sciences, 2(2), 152-161.

Ajanthan, A. (2013). The Relationship between Dividend Payout and Firm Profitability: A Study of Listed Hotels and Restaurant Companies in Sri Lanka, International Journal of Scientific and Research Publications. 3(6), 1-6.

Ajide, F.M., \& Aderemi, A.A (2014). The Effects of Earnings Management on Dividend policy in Nigeria: An Empirical Note. The SIJ Transactions on Industrial, Financial \& Business Management (IFBM), 2(3), 145-152

Akani, A.W., \& Sweneme, Y (2016). Dividend Policy and the Profitability of Selected Quoted Manufacturing Firms in Nigeria: An Empirical Analysis, Journal of Finance and Accounting, 4(4), 212-224

Al-kuwari (2009). Investigate the Determinants of Dividend Policy for the Firms listed on Gulf Co-operations Council (GCC). The Journal of Finance and Quantitative Analysis, 8(1), 47-59.

Amidu, M. (2007). How does Dividend Policy affect Performance of the firm on Ghana Stock Exchange? Investment Management and Financial Innovations, 4(2), 103-112.

Davies, T., \& Pain, B. (2002). Business Accounting \& Finance. Berkshire: McGraw-Hill.

Droughty, M. (2000). The Joy of Money. London: Simon \& Schuster Ltd.

Ezugwu C.I., \& Akubo D. (2014) Analysis of the Effect of High Corporate Tax Rate on the Profitability of Corporate Organizations in Nigeria - A Study of Some Selected Corporate Organizations, Mediterranean Journal of Social

Sciences, 5(20), 310-321. 
Jacob, E.O., \& Akinselure, O.P (2016). Impact of Dividend Policy and Earnings on Selected Quoted Companies in Nigeria, International Journal of Innovative Research and Development, 5(6), 450-460.

Kouser, R., Luqman, R., Yaseen, A., \& Azeem, M (2015). Dividend Payout Policy and Financial Crisis: Evidence from the Life Cycle Theory. Pakistan Journal of Commerce and Social Sciences, 9(2), 583-597

Kurawa, J.M., \& Ishaku, A (2014) The Effect of Corporate Governance on Dividend Policy of Listed Banks in Nigeria: A Panel Data Analysis, Research Journal of Finance, 2(8), 1-12

Marfo-Yiadom, E. \& Agyei, S.K. (2011). Dividend policy and bank performance in Ghana. International Journal of Economics and Finance, 3(4), 202-207.

Mukhtar, M.B (2015). Ownership Structure and Dividend Policy: An Analysis of Consumer Goods Industry in Nigeria, 17th International Academic Conference, Vienna, 21 June 2015, 25-38

Murekefu, T.M. \& Ouma, O.P. (2013). The Relationship between Dividend Payout and Firm Performance: A study of listed companies in Kenya. European Scientific Journal, 8(9), 199-215.

Nnadi, M.A., \& Akpomi, M. (2008). The Effect of Taxes on Dividend Policy of Banks in Nigeria, International Research Journal of Finance and Economics, 1(19), 48-55.

Odeleye, A.T (2015). Ownership Structure and Dividend Payouts of Listed Banks in Nigeria, Asian Research Journal of Business Management, 3(1), 108-119.

Odesa, J.0., \& Ekezie, A. (2015). Determinants of Dividend Policy in Quoted Companies in Nigeria. Communication Panorama African and Global Perspectives, 1(1), 1-13.

Odia, J. O., \& Ogiedu, K.O (2013). The Effect of Corporate Taxes on Dividend Policy of Banks in Nigeria. Research Journal of Finance and Accounting, 4(5), 138- 145.

Okafor, C.A., \& Mgbame C.O. (2011). 'Dividend policy and Share Price Volatility in Nigeria, Journal of Industrial, Financial \& Business Management, 9(1), 234-241.

Oloyede, J.A., and Ajayi, L.B. (2005). Effects of Dividend Policy on Stock Price. Nigerian Journal of Banking and Financial Issues, 6(7), 86-101.

Olowe R.A., \& Soyoye, L.M. (2014). Determinants of Dividend Payout in the Nigerian Banking Industry, Proceedings of 9th Annual London Business Research Conference 4 - 5 August 2014, Imperial College, London, UK, 1-23.

Pal \& Goyal (2007). “Leading Determinants of Dividend Policy” Academic Journals, 34(2), 65-89.

Pandey, N.S., \& Ashvini, N. (2016). A Study on Determinants of Dividend Policy: Empirical Evidence from FMCG Sector in India. Pacific Business Review International Journal, 1(1), 135-141.

Priya, K. \& Nimalathasan, B. (2013).Dividend Policy Ratios and Firm Performance: a case study of Selected Hotels \& Restaurants in Sri Lanka. Global Journal of Commerce and Management Perspective, 2 (6), 16-22.

Proshare (2017), 82 Quoted Companies Declared Dividends and Bonuses in 2016. Available at: https://www.proshareng.com/news/INVESTORS\%20NEWSBEAT/82-Quoted-Companies Declared-Dividendsand-Bonuses-in-2016/33352. (Accessed: $8^{\text {th }}$ May 2017).

Ranti (2013). “Determinants of Dividend Policy” International Journal of Business and Social Science, 7(17), 107119.

Sajid, G., Muhammad,B.K., Bilal, A., Shafiq, U.R and Mehran, S (2012). Taxes and Dividend Policy (The Case of Pakistan). Research Journal of Finance and Accounting, 3(10), 115.

Sakinc, I. and Gungor, S. (2015). The Relationship between Ownership Structure and Dividend: An Application in Istanbul Stock Exchange. Journal of Economics and Development Studies, 3(4), 19-30

Samuel, S.E. and Inyada, S.J. (2010). The Effect of Company Income Tax on Dividend Policy of Financial Institutions in Nigeria. Continental Journal of Social Sciences, 3(1), 1 - 6

Uwuigbe, O. Olowe, O. (2013). The Effects of Company Income Tax on Dividend Policy of Firms in Nigeria. Accounting and Auditing Economica 9(1), 79-90

Yusuf B.R (2015). Dividend Payout Ratio and Performance of Deposit Money Banks in Nigeria. International Journal of Advances in Management and Economics, 4(6), 98-105

Zameer, H., Rasool, S., Igbal, S., \& Arshad, U. (2013). Determinants of dividend policy: A case of banking sector in Pakistan Middle-East. Journal of Scientific Research, 18(3), 410-424 